\title{
PERTUKARAN SOSIAL ELIT POLITIK DALAM PEMILIHAN KEPALA DAERAH DI PROVINSI GORONTALO
}

\author{
Oleh: Apris Ara Tilome ; Andi Dody M. Putra Agustang ; Andi Agustang \\ apristiloome@yahoo.com; andidody@unm.ac.id ; andi.agustang@unm.ac.id
}

\begin{abstract}
ABSTRAK
Artikel ini bertujuan untuk membedah perspektif teoritik pertukaran sosial elit politik pemilihan kepala daerah di Provinsi Gorontalo. Metode pengumpulan data menggunakan wawancara, dokumentasi dan retrospektif. Penelitian ini menghasilkan beberapa temuan antara lain: Pertama, relasi pertukaran sosial elit politik merupakan situasi strategis yang saling bergantung, saling membutuhkan, dan sama-sama saling menguntungkan sekaligus sebagai suatu upaya konsolidasi kekuatan untuk mencapai keterpilihan/kemenangan dalam momentum pemilihan umum kepala daerah. Kedua, pola pertukaran sosial didasarkan pada sejumlah potensi kepemilikan sumberdaya elit baik figuritas, finansial, maupun kekuatan sosial yang menjadi bahan pertimbangan partai politik dalam menentukan dan memberikan restu/rekomendasi partai kepada pasangan calon kepala daerah. Ketiga, strategi pertukaran sosial adalah bagaimana elit politik memanfaatkan dan memaksimalkan sumberdaya yang dimiliki untuk mencapai kemenangan dalam kontestasi pemilihan kepala daerah. Keempat, implikasi sosiologis adalah bagaimana interaksi sosial politik itu berlangsung dalam kehidupan masyarakat pasca pemilihan calon kepala daerah. Apakah masyarakat terkotak-kotak, menimbulkan gesekan dan bagaimana upaya meredusir potensinya. Penelitian ini menyimpullkan bahwa proses suksesi kepala daerah, partai politik memanfaatkan figur pasangan calon untuk mengukuhkan pengaruh politisnya untuk mendulang dukungan dari masyarakat (voters). Walaupun pada faktanya pasangan calon kepala daerah, voters, dan partai politik tidak memiliki kedekatan hubungan baik secara ideologis maupun sosiologis.
\end{abstract}

Kata Kunci: Pertukaran Sosial, Pemilihan Kepala Daerah

\section{PENDAHULUAN}

Fenomena pertukaran sosial elit politik dalam pemilihan kepala daerah penulis awali dengan mengajukan hasil riset LSI dan SMRC (2011); Indikator Politik (2013) yang menemukan bahwa tingginya biaya politik disebabkan baik pasangan calon kepala daerah dan calon anggota legislatif maupun konstituen hanya membangun hubungan politik jangka pendek (pragmatis) dengan partai politik (www.kompas.com, 12 Desember 2013).

Relevansi temuan riset beberapa lembaga survei di atas mengindikasikan bahwa aras kiblat perpolitikan di Indonesia hingga saat ini masih belum beranjak dari persoalan perebutan kekuasaan. Sistem politik yang seharusnya mengartikulasikan kepentingan rakyat hanya menjadi sarana pencapaian tujuan kelompok-kelompok kepentingan. Oleh karena itu, pertukaran sosial elit politik 
masih menjadi momok sekaligus borok dalam perpolitikan di tanah air. Politik transaksional dan segala aspek-aspek keuangan yang menyertainya selanjutnya dikemas dalam terminologi yang lebih santun sebagai anggaran politik (political cost) juga popular sebagai political budget cycle (Rogoff, 1987; Blais \& Nadeau, 1992; Gonzales, 2002; Brender \& Drazen, 2004; Shi \& Svensson, 2006) dimana semua anggaran yang terkait dengan pembiayaan politik dianggap rasional dalam proses berdemokrasi.

Selain penelitian-penelitian dalam konteks global di atas, tema politik transaksional sudah banyak mendapat perhatian para peneliti nasional dan lokal, sebut saja misalnya Hidayat, dkk (2007) membedah relasi kekuasaan elit di tingkat lokal antara pengusaha, penguasa, dan penyelenggaraan pemerintahan daerah pasca pilkada menemukan apa yang disebutnya sebagai praktik oligarki kekuasaan. Menurutnya, basis konstruksi oligarkhi kekuasaan itu bervariasi berlandaskan pada kekuatan partai politik, ikatan kekerabatan, ikatan kesukuan, dan hubungan keluarga. Praktik oligarkhi kekuasaan itu relatif berjalan efektif dalam penyelenggaraan pemerintahan daerah karena ditopang oleh keberadaan shadow political dan business manager yang berperan sebagai aktor penghubung antara pejabat daerah dengan masyarakat pada umumnya dan kepada para pengusaha pada khususnya.

Muhtadi (2013) tentang politik uang dan dinamika elektoral memaparkan maraknya politik uang disebabkan dua hal pokok, yakni: Pertama, minimnya kedekatan pemilih terhadap partai politik. Kedua, buruknya kinerja partai politik di mata masyarakat karena banyaknya kader partai terlibat kasus korupsi. Disisi lain, Razaqtiar (2015) menelaah peran partai politik pada pemilihan kepala daerah. Pada kasus Pilkada Kabupaten Karanganyar tahun 2013 disimpulkan bahwa kemenangan pasangan calon kepala daerah tidak saja ditentukan oleh popularitas pasangan calon kepala daerah, partai politik memiliki andil penting bukan saja sebagai kendaraan politik melainkan juga sebagai sarana mempertemukan sejumlah gagasan strategis untuk menaikkan rating keterpilihan calon kepala daerah.

Demikian halnya hasil riset kuantitatif yang dilakukan Indora, Suntoro, dan Nurmalisa (2014) yang menemukan bahwa ada pengaruh signifikan antara pengaruh politik transaksional terhadap perilaku pemilih dalam pemilihan kepala daerah. Begitu juga temuan disertasi doktoral Rachim (2017) bertema politik transaksional di Kota Makassar menjelaskan bahwa kedekatan aktor politik dengan sejumlah pejabat daerah cukup memengaruhi tingkat keterpilihan calon anggota legislatif.

Temuan riset-riset terdahulu tersebut pada prinsipnya cukup menjelaskan jika proses berdemokrasi saat ini masih membuka ruang seluas-luasnya terhadap praktik pertukaran sosial elit politik. Fenomena ini sekaligus menyuburkan praktik petronase dan klientelisme dalam demokrasi. Petronase dimaknai sebagai bentuk distribusi materi atau keuntungan politik yang dilakukan oleh politisi kepada konstituennya, sedangkan klientelisme adalah karakter relasi antara politisi dengan konstituennya (Aspinall dan Sukmajati, 2015:4).

Secara subtantif, penelitian terdahulu bertema pertukaran sosial elit politik dapat dikelompokkan pada dua pola kajian, yakni: Pertama, peneliti menguraikan 
peran penting politik transaksional untuk menopang kekuatan figur calon kepala daerah, calon anggota legislatif maupun voters serta partai politik adalah suatu keadaan yang saling bergantung dan sama-sama saling menguntungkan. Kedua, politik transaksional sebagai momok dan borok yang menggerogoti sistem demokrasi karena hanya melanggengkan hubungan pragmatis setiap elemen yang terkait dengan penyelenggaraan proses politik (calon kepala daerah/calon legislatif, konstituen, dan partai politik). Alhasil, pengartikulasian kepentingan rakyat terkalahkan oleh kepentingan elit dan kelompok kepentingan secara terbatas. Hal ini sekaligus menunjukkan bahwa realitas ontologis penelitianpenelitian terdahulu itu masih bertumpu pada paradigma klasik sosiologi politik, semata terbatas pada masalah relasi patron-klien.

Berbeda dengan penelitian ini yang hendak menjelajahi ruang postruktural dan postmaterial, berfokus pada unsur-unsur dibalik realitas pertukaran sosial elit politik dalam kontestasi pemilihan kepala daerah. Unsur-unsur dibalik realitas sebagai objek ontologi (area of knowledge) tidak saja untuk mengidentifikasi pertukaran sosial elit politik secara tematik melainkan bagaimana pertukaran sosial itu bekerja, dikonstruksikan, atau dioperasionalkan dibalik realitas yang tampak saja. Pertukaran sosial elit politik, pemilih, dan partai politik sebagai manifestasi pencapaian tujuan pragmatis yang menciderai sistem pemilihan umum bukan sebagai suatu gejala yang alamiah melainkan representasi kompleksnya multi kepentingan politik.

Kebaruan ontologis (state of the art) penelitian ini diperkuat oleh fakta sosiologis bahwa proses penyelenggaraan pemilihan kepala daerah, termasuk di Provinsi Gorontalo tahun 2017 masih diwarnai oleh adanya pertukaran sosial elit politik. Fenomena politik transaksional di Provinsi Gorontalo, Kabupaten Gorontalo, dan Kabupaten Bone Bolango sebagai lokus penelitian bahkan lebih menarik untuk ditelaah. Misalnya, pemilihan gubernur tahun 2017 yang dimenangkan oleh Rusli Habibie dan Idris Rahim sebagai kader Partai Amanat Nasional justru meraih kemenangan melalui Partai Golkar, karena Partai Amanat Nasional memberikan rekomendasi kepada pasangan calon non kader. Di Kabupaten Gorontalo, pemilihan kepala daerah dimenangkan oleh pasangan calon dari kalangan kader partai politik. Sedangkan di Kabupaten Bone Bolango yang merupakan basis Partai Persatuan Indonesia memberikan rekomendasi kepada non kader tetapi mengalami kekalahan.

Politik transaksional cakupannya sangat luas, bisa menyentuh seluruh aktivitas politik. Baik pada pemilihan Presiden, Gubernur, Walikota/Bupati bahkan sampai ditingkat kepala Desa memerlukan transaksi politik. Biaya yang dikeluarkan saat Pilpres maupun Pemilukada menjadi beban yang harus dikembalikan saat seseorang telah memperoleh kekuasaan.

Persaingan antar partai politik membuat masing-masing calon penguasa berusaha sekuat tenaga menebar pengaruh pada publik untuk mendapat dukungan Partai. Tindakan ini sejatinya menyuburkan money politic di kalangan elit partai dan dapat mempengaruhi demokratisasi pemilihan kepala daerah.

Dalam perspektif sosiologi politik, dapat dipastikan ada pertukaran sosial politik oleh elit politik dengan pemilih. Realitas politik memang meniscayakan sikap saling ketergantungan dan saling menguntungkan (simbiosis mutualisme) 
antara patron-klien. Uang yang awalnya merupakan alat transaksi ekonomi bertransformasi menjadi alat yang efektif untuk memperoleh keuntungan non ekonomi kursi kekuasaan. Tampak jelas bahwa calon kepala daerah sulit mendapat dukungan jika tidak disertai uang. Uang digunakan bukan saja untuk mendapat dukungan dari konstituen tetapi juga untuk mengikat dukungan konstituen. Dengan demikian, pertukaran sosial elit politik sesungguhnya mencerminkan ekspresi budaya, hasil konstruksi sosial masyarakat yang membentuk satu mata rantai penting antara peristiwa-peristiwa politik dengan perilaku-perilaku individual dalam memberikan reaksi terhadap peristiwaperistiwa tersebut (lihat Gaffar, 1989:79).

Pada dasarnya politik adalah kompromi atau sharing kekuasaan. Hal ini bukan hanya di Indonesia, tapi juga diseluruh dunia yang menganut sistem demokrasi. Politik adalah proses pembagian kekuasaan, dimana seseorang atau sekelompok orang yang meraih kekuasaan akan berbagi kekuasaan dengan orang lain.

Biasanya, pembagian kekuasaan tersebut berkaitan dengan koalisi politik yang sebelumnya dibangun. Koalisi inilah yang memungkinkan adanya pertukaran sosial elit politik. Sebelum koalisi dibangun, maka pertukaran elit politik itu harus sudah disepakati. Jika dalam pelaksanaannya ada pengkhianatan, maka kesepakatan politik itu bisa dievaluasi atau tidak dilakukan sama sekali. Yang menarik dari peneliti adalah pertukaran sosial dalam elit politik dikalangan elit partai yang tidak mempertimbangkan etika politik dalam menentukan calon kepala daerah. Di Gorontalo adalah Ketua Partai politik A menjual partainya kepada calon kepala daerah yang tidak memiliki partai, dan pemilik partai mencalonkan diri dengan partai lain yang memenuhi syarat dalam pencalonan kepala daerah.

\section{PERSPEKTIF TEORI}

Untuk menjelaskan fenomena pertukaran sosial elit politik sebagai permasalahan pokok dalam penelitian ini, selanjutnya akan diketengahkan tematika teoritik tentang artikulasi kekuasaan dalam kehidupan sosial khususnya konsep kekuasaan Michel Foucault dan akan dielaborasi baik secara parsial maupun komprehensif pada hal-hal memiliki pertautan yang kuat dengan kontestasi pemilihan kepala daerah pada lokus penelitian. Kedua, menelaah keragaman partisipasi politik dan sistem pengrekrutan politik termasuk di dalamnya biaya politik sebagai landasan konseptual hasil penelitian.

\section{A. Artikulasi Kekuasaan dalam Kehidupan Sosial}

Titik sentral studi sosiologi berhubungan dengan tingkah laku manusia dalam satu konteks kehidupan bermasyarakat. Jika asumsi ini disepakati, maka menjadi penting untuk menerapkan studi politik dalam kaitan kekuasaan pada konteks kehidupan masyarakat yang sama. Oleh karena itu, persinggungan antara studi sosiologi dan studi politik berada pada domain kajian yang sama, yakni tentang kekuasaan sosial.

Membincangkan kekuasaan dalam konteks kehidupan sosial akan lebih bermakna jika menjelajahi gagasan mengenai kekuasaan para filsuf ternama abad 
pertengahan seperti misalnya Thomas Aquinas, Thomas Hobbes, Karl Marx, atau Max Weber. Bagi Aquinas, kekuasaan hanyalah suatu kenyataan fisik dan sosial tetapi tidak memuat suatu wewenang. Menurutnya, tidak ada seseorang manusia yang secara asali mempunyai wewenang atas manusia lain, karena yang berwenang atas kekuasaan itu hanyalah Tuhan (Suseno, 1986:6).

Berdasarkan hal tersebut, Aquinas secara radikal menuntut legitimasi etis penggunaan kekuasaan oleh manusia. Inti pemikiran Aquinas adalah kekuasaan pada pokoknya hanya benar dan baik sejauh berjalan dengan dalam batas-batas hukum yang presisi (tepat/akurat), sedangkan hukum sendiri harus menunjang tujuan negara, yaitu mengusahakan kesejahteraan umum dan bukan kepentingan pribadi penguasa atau kelompok tertentu. Makna kekuasaan tersebut sangat berbeda dengan pandangan Hobbes yang meletakkan kekuasaan sebagai kekuatan institusional yang bersifat formal dari negara dengan menerapkan manipulasi psikologis berupa ancaman dan ketakutan. Bagi Hobbes, negara harus kuat tanpa tanding sehingga dapat memastikan, seperlunya memaksakan masyarakat untuk taat pada peraturan dan negara wajib menetapkan tatanan hukumnya. Demikian halnya pandangan Marxisme dimana kekuasaan sebagai properti kepemilikan yang dapat dikuasai oleh satu orang atau kelompok tertentu untuk melemahkan orang lain atau kelompok tertentu, bahkan pandangan kaum Weberian yang hanya membatasi kekuasaan itu sebagai kemampuan subyektif aktor untuk mendominasi aktor lain.

Gordin dan Klingemann (Ahmad, 2012:15) mendefinisikan politik sebagai penggunaan kekuasan sosial (social power) yang dilakukan secara terbatas. Hal ini tak lain karena eksistensi kekuasaan hadir dalam kehidupan sosial dan keberadaannya juga terkait dengan legitimasi sosial dari kekuasaan itu sendiri. Kekuasaan sosial dalam hal ini tidak bersifat absolut, namun ada beragam batasan dari kekuasaan lainnya yang selalu hadir secara bersamaan dan tak terhindarkan. Defenisi paling mendekati makna kekuasaan Foucault yang mengartikulasikan bahwa kekuasaan itu tersebar, tidak dapat dilokalisasi, sebagai sebuah tatanan yang dihubungkan dengan jaringan-jaringan (networks), ditandai adanya struktur kegiiatan-kegiatan yang produktif tidak represif, serta melekat pada kehendak untuk mengetahui (Haryatmoko, 2002:37).

Dalam kaitan ketidakseimbangan perolehan imbalan di antara dua orang yang melakukan pertukaran sosial, Homans mengemukakan konsep kekuasaan (power) sebagai kemampuan mengendalikan imbalan atau hukuman dalam suatu pertukaran sosial. Seorang yang memiliki kekuasaan atau penguasa berarti ia mampu membuat pihak yang dikuasai melakukan apa pun yang dikehendakinya. Karena pihak yang dikuasai tidak mempunyai kemampuan untuk memberikan baik imbalan maupun hukuman kepada pihak penguasa. Kemampuan untuk memberikan imbalan atau sanksi yang dimiliki oleh penguasa, dampaknya sama saja bagi pihak yang dikuasai, yakni posisi yang dikuasai bergantung pada penguasa.

Kontekstualisasi pertukaran sosial elit politik dalam pemilihan umum kepala daerah sebagai tematika utama penelitian ini memaknai bahwa kekuasaan itu menyebar sebagai suatu bentuk situasi strategis yang kompleks dalam jalinan 
relasi sosial yang tengah berlangsung. Foucault (Adil, 2016:19) menyebutkan lima proposisi kekuasaan yang diuraikannya sebagai berikut:

1. Kekuasaan bukan sesuatu yang didapat, diraih, digunakan, atau dibagikan sebagai sesuatu yang dapat digenggam atau bahkan dapat juga punah; tetapi kekuasaan dijalankan dari berbagai tempat dari relasi yang terus bergerak.

2. Relasi kekuasaaan bukanlah relasi hirarki struktural yang mengandaikan ada yang menguasai dan ada yang dikuasai.

3. Kekuasaaan itu datang dari bawah yang mengandaikan bahwa tidak ada lagi distingsi binary opositions karena kekuasaan itu mencakup dalam keduanya.

4. Relasi kekuasaan itu bersifat intensional dan non-subyektif.

5. Dimana ada kekuasaan, disitu pula ada anti kekuasaan (resistance), dan resistensi tidak berada di luar relasi kekuasaan itu, setiap orang dalam kekuasaan, tidak ada satu jalanpun untuk keluar darinya.

Kelima proposisi Foucault di atas menunjukkan betapa kekuasaan merupakan kompleksitas bentuk dari situasi yang strategis, dan untuk memahami kompleksitas kekuasaan yang berelasi seperti jaringan itu pula ia mengajukan lima pendekatan (Upe, 2016:19), yakni:

1. Desentralisasi analisis kekuasaan, yaitu menolak bentuk kekuasaan sentralistik. Tujuannya untuk melihat eksremitas kekuasaan dan pelbagai teknik materil mengintervensi kehidupan.

2. Mengamati kekuasaan secara eksternal dengan mendekatkannya pada kajian-kajian empiris dimana lokasi yang bentuk-bentuk kekuasaannya memiliki efek.

3. Tidak menganggap kekuasaan sebagai hak kepemilikan (property right), melainkan sebagai sebuah jaringan yang melibatkan individu sebagai subyek dan objek kekuasaan.

4. Kekuasaan tidak bekerja dari atas ke bawah (top down) tetapi dari bawah ke atas (bottom up).

5. Tidak memulai dengan ideologi dan mengekplorasi instrument apa yang digunakan, tetapi memulai dengan mekanisme dan praktik-praktik, serta menjelajahi bagaimana aktor membentuk ideologi dan pengetahuan.

Mencermati kelima pendekatan di atas, maka dapat dipahami bahwa kekuasaan tidaklah beroperasi secara negatif sebagai alat yang dapat digunakan untuk melakukan penekanan/penindasan kepada individu. Kekuasaan dalam konteks ini beroperasi secara positif dan produktif, walaupun wujud kekuasaan itu tidaklah nampak dan tidak disadari/dirasakan sebagai praktik-praktik yang mengendalikan individu itu, tetapi efek-efek dari praktik kekuasaan itu dapat diketahui.

\section{B. Teori Pertukaran}

Akar teori pertukaran berasal dari behaviorisme dalam ilmu psikologi. Oleh karena itu, teori pertukaran familiar disebut sebagai sosiologi perilaku. 
Sosiologi perilaku sebagai reduksi ilmu psikologi tertarik pada hadiah (atau penguat) dan ongkos (atau hukuman). Hadiah ditentukan oleh kemampuannya memperkuat perilaku, sedangkan ongkos mengurangi kemungkinan perilaku. Gagasan tentang hadiah dan ongkos dalam behaviorisme inilah yang memengaruhi teori pertukaran.

Homans mengemukakan bahwa tindakan yang berkenaan dengan suatu kemauan yang mengakibatkan adanya suatu ganjaran dan hukuman bagi orang lain. Oleh karena itu, pertukaran itu saling dapat menguntungkan atau sepanjang dianggap saling menguntungkan oleh kedua belah pihak. Homans mengembangkan beberapa proposisi yang mendasari pembentukan teori pertukarannya, yakni:

\section{a. Proposisi Sukses (the success proposition)}

Untuk semua tindakan yang dilakukan seseorang, semakin sering tindak khusus seseorang diberi hadiah, semakin besar kemungkinan orang melakukan tindakan itu. Ada beberapa hal yang ditetapkan Homans mengenai proposisi ini, yakni: Pertama, walaupun benar bahwa makin sering hadiah diterima menyebabkan makin sering tindakan dilakukan, namun hal ini bukan berarti berlangsung tanpa batas karena di saat-saat tertentu individu benar-benar tidak dapat bertindak seperti itu sesering mungkin. Kedua, makin pendek jarak waktu antara perilaku dan hadiah, makin besar kemungkinan orang mengulagi perilaku. Sebaliknya, makin lama jarak waktu antara perilaku dan hadiah, makin kecil kemungkinan orang mengulangi perilaku. Ketiga, pemberian hadiah secara intermiten lebih besar kemungkinannya menimbulkan perulangan perilaku ketimbang menimbulkan hadiah yang teratur. Hadiah yang teratur menimbulkan kebosanan dan kejenuhan, sedangkan hadiah yang diterima dalam jarak waktu yang tidak teratur sangat mungkin menimbulkan perulangan perilaku.

\section{b. Proposisi Nilai (the value proposition)}

Makin tinggi nilai hasil tindakan seseorang bagi drinya, makin besar kemungkinan ia melakukan tindakan itu. Apabila hadiah yang diberikan masingmasing kepada orang lain amat bernilai maka makin besar kemungkinan aktor melakukan tindakan yang diinginkan ketimbang jika hadiahnya tidak bernilai. Maknanya, jika hadiah itu bernilai positif maka makin besar pula kemungkinan melahirkan perilaku yang diinginkan. Sebaliknya, jika hukuman adalah bernilai negatif, maka makin besar pula kemungkinan aktor melakukan tindakan yang tidak diinginkan.

\section{c. Proposisi Deprivasi - Kejemuan (the deprivation - satiation proposition)}

Homans melihat bahwa rutinnya pemberian dan penerimaan hadiah memungkinkan hadah itu menjadi tidak bernilai. Maka durasi waktu pemberian hadiah harus diatur secara proporsional agar tidak menimbulkan kejemuan. Oleh karena itu, Homans meletakkan konsep biaya dan keuntungan sebagai sesuatu yang dapat mengikat perulangan perilaku itu. Biaya tiap perilaku didefinisikan sebagai hadiah yang hilang karena tidak jadi melakukan tindakan yang 
direncanakan, sedangkan keuntungan dilihat sebagai hadiah yang lebih besar yang diperoleh atas biaya yang dikeluarkan.

\section{d. Proposisi Persetujuan - Agresi (the aggression - approval proposition)}

Dalam proposisi ini Homans mengembangkan dua kemungkinan konseptual yang mengacu pada emosi positif dan emosi negarif, yakni: Proposisi A: Bila tindakan orang tidak mendapatkan hadiah yang ia harapkan atau menerima hukuman yang tidak diharapkan, ia akan marah. Besar kemungkinan ia akan melakukan tindakan agresif dan akibatnya tindakan demikian makin bernilai baginya. Proposisi B: Bila tindakan seseorang menerima hadiah yang ia harapkan, terutama hadiah yang lebih besar daripada yang ia harapkan atau tidak menerima hukuman yang ia bayangkan, maka ia akan puas; ia makin besar kemungkinannya melakukan tindakan yang disetujui dan akibat tindakan seperti itu akan makin bernilai baginya.

\section{e. Proposisi Rasionalitas (the rationality propotion)}

Dalam memilih berbagai tindakan alternatif, seseorang akan memilih satu diantaranya yang dia anggap saat itu memiliki nilai (value) sebagai hasil dikalikan dengan probabilitas (kemungkinan) untuk mendapatkan hasil yang lebih besar. Proposisi ini bertujuan untuk memaksimalkan kegunaan dari satu alternatif tindakan yang dilakukan individu.

Mencermati kelima proposisi teori pertukaran Homans di atas, dapatlah disimpulkan bahwa individu dalam berlangsungnya proses interaksi sosial pada dasarnya adalah aktor yang mencari keuntungan dari tindakan-tindakan yang diwujudkannya.

\section{METODE PENELITIAN}

Paradigma penelitian penelitian ini adalah konstruktivis. Paradigma konstruktivis terutama didasarkan pada asumsi ontologis bahwa realitas hubungan elit politik terbentuk sebagai hasil konstruksi sosial yang dijembatani oleh sistem nilai tertentu (value of system), bisa bersifat relatif atau tentatif sesuai dengan kepentingan yang ingin dicapai. Penjelasan ontologis pertukaran sosial elit politik dapat ditelisik pada derajad hubungan strukturasinya yang saling pengaruh memengaruhi berupa persaingan dan kerjasama.

Epistemologis paradigma konstruktivis dijembatani nilai transaksional subyektif secara hermeneutik dan dialektik antara peneliti dengan fenomena pertukaran sosial elit politik. Maknanya, metodologi yang diigunakan mengutamakan analisis komprehensif dan kontekstual untuk menemukan kebenaran dengan cara mengungkap kebenaran yang sesungguhnya di balik realitas yang terjadi. Karena metodologi penelitian ini menggunakan analisis komprehensif dan kontekstual maka pendekatan yang digunakan adalah pendekatan kualitatif (Ratna, 2010).

Dengan demikian, konsekwensi aksiologisnya pada kontribusi wacana dan pengetahuan tentang masalah tersebut digunakan sebagai saluran dalam menentukan dan menyuarakan pilihan oleh semua pemangku kepentingan dalam 
satu momentum pemilihan umum kepala daerah di Provinsi Gorontalo khususnya, dan di Indonesia pada umumnya.

Metode yang digunakan adalah komparatif. Metode komparatif pada dasarnya bersifat ex po facto dimana pengumpulan data melalui kejadian yang sudah selesai. Walau kelemahan metode ini tidak mungkin mengetahui penyebab yang digunakan sebagai dasar pembanding karena tidak adanya kontrol terhadap variabel bebas. Namun demikian dapat diatasi dengan melipatgandakan argumentasi yang memungkinkan terjadinya hubungan kausal dan pradugapraduga dalam rangka penarikan kesimpulan (Ratna, 2010:333).

\section{HASIL DAN PEMBAHASAN}

Manusia sebagai zon politicon (Aristoteles) atau homo homini socius (Adam Smith) adalah makhluk bermasyarakat (sosial). Manusia sebagai makhluk bermasyarakat berinteraksi satu sama lain untuk memenuhi hajat hidupnya. Manusia sebagai makhluk bermasyarakat memiliki sejumlah penciri yang khas, berbeda satu dengan lainnya seperti misalnya fisik, bakat, emosi, kebutuhan, citacita, inisiatif, perilaku dan lain sebagainya yang kesemua hal itu memicu lahirnya tumbukan antar kepentingan. Perbedaan-perbedaan itu pula yang senantiasa menempatkan masyarakat dalam situasi penuh konflik.

Artikulasi kebutuhan individu maupun kolektif pada dasarnya membutuhkan kompetisi, baik itu yang sifatnya individual (private needs) maupun publik (public needs). Kebutuhan individual sangat dipengaruhi oleh kearah mana kebutuhan publik terpenuhi, sebab akan sangat sulit memenuhi kebutuhan individu jika kebutuhan publik tidak tersedia. Untuk menghindari munculnya tumbukan kepentingan dibutuhkan upaya-upaya sadar dan kolektif guna tercipta keteraturan, dan keteraturan itu pada dasarnya hanya bisa diwujudkan melalui politik.

Politik dimaknai secara beragam oleh para ahli. Tidak ada satu konsensus yang disepakati. Politik dapat diartikulasikan sebagai pembagian kekuasaan (sharing power), dapat juga dimaknai sebagai usaha mempengaruhi orang lain untuk mencapai tujuan tertentu, atau politik itu tentang siapa mendapatkan apa, kapan, dan bagaimana ia didapatkan. Yang pasti, politik itu melingkupi semua aspek kehidupan sosial, budaya, ekonomi, dan keagamaan.

Menurut Rush dan Althoff (2013:128) partisipasi politik itu bersifat luas. Dalam masyarakat primitif, dimana politik erat terintegrasi dengan kegiatan masyarakat pada umumnya, partisipasi condong tinggi dan mungkin sulit untuk dibedakan dari kegiatan lainnya. Akan tetapi, dalam masyarakat berkembang, karena adanya kombinasi dan institusi dan pengaruh modern dan tradisional, partisipasi mungkin dibatasi faktor-faktor seperti tingkatan melek huruf dan masalah umum dari komunikasi. Berlawan dengan hal ini ialah partisipasi politik dalam masyarakat totaliter, dalam beberapa bentuk partisipasi mungkin sangat tinggi, dan lainnya mungkin sangat rendah.

Institusi politik, kelembagaan politik dan sistem politik mutlak dibutuhkan dalam berdemokrasi. Menurut Ahmad (1992:28), yang dimaksud institusi politik merupakan institusi yang tercipta dalam kehidupan publik yang menciptakan 
aturan main (rule of game) yang disepakati baik secara formal maupun informal dalam interaksi kehidupan masyarakat. Institusi politik memiliki sejumlah peran penting antara lain: Pertama, menentukan siapakah para aktor politik yang memiliki legitimasi politik. Kedua, menentukan bagaimana ragam dan jumlah aktor yang berkembang dalam kelembagaan politik dan sistem politik. Ketiga, menjadi referensi dan panduan bagaimana kecenderungan perilaku aktor politik. Keempat, menentukan bagaimana kecenderungan informasi politik yang akan dan hendak dimiliki dan dibutuhkan oleh para aktor politik terhadap institusi politik lainnya. Kelima, menentukan bagaimana logika kelayakan (logic of approriateness) dari perilaku aktor politik dalam situasi tertentu.

Pertukaran sosial dalam proses politik adalah niscaya. Dalam setiap momentum pemilihan umum, elit, voters, dan partai politik senantiasa berada dalam situasi strategis, saling bergantung, saling membutuhkan, dan tentu saja saling menguntungkan. Pertukaran sosial itu ada kalanya bahkan umumnya bersifat pragmatis untuk tujuan sesaat.

Ada banyak kasus dimana calon kepala daerah bukan kader partai politik, demikian halnya partai politik sekadar menjadi kendaraan politik calon kepala daerah, sementara voters tidak punya kedekatan hubungan dengan partai politik. Keadaan ini pada prinsipnya merupakan situasi strategis untuk dimanfaatkan elit politik dalam memaksimalkan strategi pertukaran sosial untuk mencapai kemenangan.

Mencermati permasalahan yang diajukan pada bab terdahulu, maka setidaknya ada tiga pokok persoalan yang perlu dianalisis, yakni proses pertukaran sosial elit; pengaruh elit terhadap pengurus partai politik dalam menentukan calon kepala daerah, dan dampak sosiologis pertukaran sosial elit terhadap pemilih (voters).

Relasi pertukaran sosial elit politik adalah hubungan elit politik (calon kepala daerah), partai politik, dan pemilih dalam satu situasi strategis yang saling bergantung, saling membutuhkan, dan sama-sama saling menguntungkan sekaligus sebagai suatu upaya konsolidasi kekuatan untuk mencapai keterpilihan/kemenangan dalam momentum pemilihan umum kepala daerah.

Pola pertukaran sosial didasarkan pada sejumlah potensi kepemilikan sumberdaya elit baik figuritas, finansial, maupun kekuatan sosial yang menjadi bahan pertimbangan partai politik dalam menentukan dan memberikan restu/rekomendasi partai kepada pasangan calon kepala daerah.

Strategi pertukaran sosial adalah bagaimana elit politik memanfaatkan dan memaksimalkan sumberdaya yang dimiliki untuk mencapai kemenangan dalam kontestasi pemilihan kepala daerah.

Implikasi sosiologis adalah bagaimana interaksi sosial politik itu berlangsung dalam kehidupan masyarakat pasca pemilihan calon kepala daerah. Apakah masyarakat terkotak-kotak, menimbulkan gesekan dan bagaimana upaya meredusir potensinya.

Di Provinsi Gorontalo terjadi praktik pertukaran sosial antara partai politik dalam menentukan calon kepala daerah yang berhubungan dengan aspek sosiologis politik serta dengan mempertimbangkan aspek risiko wilayah dan lingkungannya. 
Provinsi Gorontalo memiliki 1 (satu) Kota dan 5 (lima) kabupaten yang sejak pemilihan umum kepala daerah tahun 2005 hingga tahun 2017 terindikasi kuat terjadi praktik pertukaran sosial dalam elit politik.

Dalam proses suksesi kepala daerah, partai politik memanfaatkan figur pasangan calon untuk mengukuhkan pengaruh politisnya untuk mendulang dukungan dari masyarakat (voters).

Pasangan calon kepala daerah, voters, dan partai politik tidak memiliki kedekatan hubungan baik secara ideologis maupun sosiologis.

Paradigma politik antara calon kepala daerah, voters, dan partai politik berorintasi pada pemanfaatan situasi strategis yang bersifat pragmatis untuk mencapai tujuan sesaat.

\section{SIMPULAN}

Sistem pengrekrutan politik untuk jabatan politik di pelbagai negara yang menganut demokrasi memiliki tingkat keberagaman yang berbeda-beda. Di Indonesia, sistem rekrutmen politik oleh partai politik dilaksanakan dalam rangka untuk menjaring calon anggota partai, bakal calon anggota legislatif daerah dan pusat, bakal calon kepala daerah (gubernur; bupati; wali kota), serta bakal calon presiden dan wakil presiden (Undang-Undang Nomor 2 Tahun 2008). Dalam konteks ini partai politik merupakan sarana pendidikan politik bukan saja bagi anggotanya tetapi juga masyarakat pada umumnya dalam rangka penyerapan dan penyarluran aspirasi politik masyarakat untuk mengikat kebijakan-kebijakan politik yang dijalankan negara.

Pengrekrutan politik merupakan suatu proses pertahanan sistem yang dilembagakan secara parsial. Marvick (2008) mengemukakan bahwa kesempatankesempatan dalam politik hampir tidak terhindarkan ditandai dengan unsur-unsur kooptasi. Menurutnya, para aspiran karir politik melintasi ambang batas yang tidak bertepi ketika mereka diperhatikan secara serius dalam menangani pekerjaan tertentu oleh mereka yang mengontrol sumber-sumber daya politik yang penting untuk mendapatkannya dan mempertahankannya. Pada akhirnya, proses pengrekrutan politik itu berdampak kurang memberikan banyak pengaruh antar pribadi, tetapi ketika pengaruh-pengaruh seperti itu datang ketika seseorang dapat menunjukkan kecakapan tertentu, bisa menggalang pengikut, bisa menyertakan pengetahuan yang dimilikinya atau sebaliknya mempengaruhi kolega-koleganya. Maknanya, rekruitmen politik tersebut didasarkan pada integritas dan kapabilitas personal.

Pengrekrutan politik bukan saja berkonsekwensi pada mekanisme politik melainkan juga pada aspek ekonomi. Realitasnya, pengrekrutan politik sulit terlaksana tanpa kontribusi ekonomi calon yang direkrut, khususnya calon kepala daerah. Semakin besar kontribusi ekonomi yang diberikan kepada partai politik akan semakin besar pula mendapatkan rekomendasi partai untuk mengikuti pemilihan kepala daerah. Adapun calon legislatif misalnya, kontribusi ekonomi itu berlaku pasca memenangkan pemilihan dan berhasil menduduki jabatan legislatif.

Kontribusi ekonomi kepala daerah kepada partai politik dalam sistem politik saat ini masih dianggap niscaya, lantaran partai politik sesungguhnya tidak 
memiliki biaya operasional dan justru selama ini hanya mendapatkan subsidi dari pemerintah, itupun hanya dalam jumlah kecil di tingkat pusat. Hal ini sekaligus menyebabkan ongkos politik menjadi mahal dan implikasinya pada maraknya penangkapan aktor politik akibat terlibat dalam pusaran korupsi.

\section{Daftar Pustaka}

Ahmad, Nyarwi. 2012. Manajemen Komunikasi Poltik dan Marketng Politik. Sejarah, Perspektif, dan Perkembangan Riset. Yogyakarta: Pustaka Zaman.

Auerbach, F. Carl dan Silverstein, B. Louis. 2003. Qualitative Data. New York: New York University Press.

Aspinall, Edward dan Sukmajati, Mada. 2015. Politik Uang di Indonesia: Petronase dan Klientelisme pada Pemilu Legislatif 2014. Yogyakarta: Departemen Politik dan Pemerintahan UGM.

Firmanzah. 2008. Marketing Politik. Antara Pemahaman dan Realitas. Jakarta: Yayasan Obor Indonesia.

Gaffar, Afan. 1989. Beberapa Aspek Pembangunan Politik - Sebuah Bunga Rampai. Jakarta: Rajawali Pers.

O'Donoghue, Tom and Punch, Keith. 2003. Qualitative Educational Research In Action. London and New York: Routledge Falmer.

Ratna, Nyoman Kutha. 2010. Metodologi Penelitian (Kajian Budaya dan Ilmu Sosial Humaniora Pada Umumnya). Yogyakarta: Pustaka Pelajar.

Ritzer, George dan Goodman, Douglas J. 2007. Teori Sosiologi Modern. Jakarta: Kencana.

Satori, Djam'an dan Komariah, Aan. 2010. Metodologi Penelitian Kualitatif. Bandung: Alfabeta.

Suseno, Frans Magnis. 1986. Kuasa dan Moral. Jakarta PT. Gramedia.

Tabroni, Roni. 2014. Marketing Politik. Media dan Pencitraan di Era Multipartai. Yogyakarta: Graha Ilmu.

\section{Bahan Bacaan Lainya}

Agustang, A. (1999). INTERAKSI SOSIAL DAN PERUBAHAN STRUKTUR KOMUNITAS. Universitas Padjadjaran Bandung.

Agustang, A. (2009). SIMBOLIKHAJI: Studi Deskriptif Analitik pada Orang Bugis. Al-Qalam, 15(2), 317-334.

Agustang, A. (2014). LIFE BEHAVIOR OF SOCIETY, FIVE CASES ON FAMILY OF DIABETES MELLITUS PATIENTS IN MAKASSAR. International Journal of Academic Research, 6(1).

Agustang, A. (2018). PERILAKU MEROKOK REMAJA SISWA SMA NEGERI 1 SINJAI UTARA KABUPATEN SINJAI. Jurnal Ilmiah Kesehatan Diagnosis, 13(1), 93-99.

Agustang, A. (2021a). Filosofi Research Dalam Upaya Pengembangan Ilmu. OSF 
Preprints.

Agustang, A. (2021b). Teknologi Partisipasi Metode Fasilitasi Pembuatan Keputusan Partisipatif. OSF Preprints.

Agustang, A., \& Adam, A. (2020). INSTITUTIONAL FAILURES IN THE WORLD OF EDUCATION IN SCHOOLS FOR CHILDREN VICTIMS OF PARENTS. Asian Journal of Social Sciences \& Humanities, 9(2), $18-26$.

Agustang, A., \& Indah, A. M. (2021). Andi Asrifan. 2021.“. KONSTRUKSI SOSIAL JANDA TEREKSPLOITASI (STUDI KASUS DI KELURAHAN TETEBATU KECAMATAN PALLANGGA KABUPATEN GOWA).” OSF Preprints. January, 10.

Agustang, A., \& Mustafah, M. Y. (2017). METROSEKSUAL DIKOTA MAKASSAR.

Agustang, A., \& Oruh, S. (2021). KESEJAHTERAAN PSIKOLOGIS (studi Pada Dewasa Madya Yang Belum Menikah Di Kota Makassar).

Agustang, A., Saleh, S., Rasyid, R., \& Agustang, A. T. P. (2019). Pengembangan profesionalisme guru SMP Negeri 1 Duampanua Kabupaten Pinrang melalui pelatihan penulisan karya tulis ilmiah. Seminar Nasional Pengabdian Kepada Masyarakat, 2019(2).

Agustang, A., Suardi, S., Putra, A. D. M., \& Oruh, S. (2021). Pemberdayaan Guru Mata Pelajaran Sosiologi Melalui Literasi Digital Berbasis Quick Response Code di Kecamatan Bissappu Kabupaten Bantaeng. Abdi: Jurnal Pengabdian Dan Pemberdayaan Masyarakat, 3(2), 175-188.

Agustang, A. Y. A., Herman, H., Said, M., \& Agustang, A. (2021). Upaya Guru IPS Dalam Meningkatkan Motivasi Belajar Siswa Pada Masa Covid 19 Di SMP. Phinisi Integration Review, 4(1), 144-149.

Ahriani, A., Agustang, A., Adam, A., \& Upe, A. (2020). The Multiple Roles of Women in Poor.

Akbar, H., Oruh, S., \& Agustang, A. (2021). Indeks Prediktif Kejadian Demam Berdarah Dengue (DBD) Berbasis Perilaku Sosial Masyarakat Di Kabupaten Indramayu. Jurnal Kesehatan, 14(2 SE-), 76-82. https://doi.org/10.32763/juke.v14i2.289

Al Yakin, A., \& Agustang, A. (2020). SELEBRIFIKASI DAN ELEKTABILITAS; MENAKAR RESPON PUBLIK.

Alamsyah, A., Agustang, A., Adam, A., \& Alim, A. (2021). Partisipasi Teritorial Masyarakat Lingkar Tambang Morosi Kabupaten Konawe. Seminar Nasional LP2M UNM.

Alim, A., Agustang, A., \& Adam, A. (2021). Transformation of Consumption Behavior of the Poor in the Case of Malnutrition: Health Sociology Study with Participatory Approach in Makassar City, Indonesia. Open Access 
Macedonian Journal of Medical Sciences, 9(E), 598-607.

AM, S. A., Agustang, A., Mustadjar, M., \& Tahmir, S. (2020). Mobility and Social Change of the Economy of Indonesian Migrant Workers in Indonesia. Solid State Technology, 63(5), 408-417.

Aminah, S., Agustang, A., Idkhan, A. M., \& Rifdan, R. (2021). KUALITAS PELAYANAN PUBLIK PADA KANTOR PERTANAHAN KABUPATEN PANGKAJENE DAN KEPULAUAN. JISIP (Jurnal Ilmu Sosial Dan Pendidikan), 5(4).

Amran, N. G., \& Agustang, A. (2020). Implementasi Kurikulum 2013 Dalam Peningkatan Kompetensi Psikomotorik Dan Afektif Siswa. Phinisi Integration Review, 3(2), 179-184.

Andini, N. F., \& Agustang, A. (2021). SISTEM PERJODOHAN ANAK DI KECAMATAN MANGGALA KOTA MAKASSAR. Pinisi Journal of Sociology Education Review, 1(2), 192-198.

Andriana, Agustang, A., Idkhan, A. M., \& Hasriadi. (2021). Daya Tanggap Pelayanan Unit Gawat Darurat di Puskesmas Sarjo Kabupaten Pasangkayu . Journal Governance and Politics (JGP), l(2 SE-Articles). https://e-journal.iyb.ac.id/index.php/jgp/article/view/201

Ardiansyah, A. A., \& Agustang, A. (2018). MAHASISWI BERKELUARGA DI FAKULTAS ILMU SOSIAL UNIVERSITAS NEGERI MAKASSAR. JURNAL SOSIALISASI, 19-23.

Arham, M., \& Agustang, A. (2021). PERUBAHAN MEDIA BERMAIN DAN PERGESERAN GAYA HIDUP ANAK DI LINGKUNGAN BULU KECAMATAN MATTIRO BULU KABUPATEN PINRANG. Pinisi Journal of Sociology Education Review, 1(2), 22-29.

Arifin, L., Agustang, A., \& Idkhan, A. M. (2021). Analysis of the Challenges of Motor Vehicle Tax Revenue at the Technical Service Unit Office Revenue. Jurnal Ad'ministrare, 8(1), 427-434.

Aris, Agustang, A., \& Idkhan, A. M. (2021). Efektifitas Pelayanan Aparatur Sipil Dalam Meningkatkan Pelayanan Publik. Journal Governance and $\begin{array}{llll}\text { Politics } & \text { (JGP), } & 1(2 & \text { SE-Articles). }\end{array}$ https://jurnal.iyb.ac.id/index.php/jgp/article/view/208

Arisal, A., Agustang, A., \& Syukur, M. (2020). Diskriminasi Sosial Anak Penderita Kusta di Kota Makassar. Phinisi Integration Review, 3(2), 297-304.

Arpin, Agustang, A., \& Idkhan, A. M. (2021). Pengaruh Penerapan Model Dicovery Learning Terhadap Hasil Belajar Siswa Pada Mata Pelajaran IPA SD Inpres Tamalanrea V Kota Makassar. Journal Governance and $\begin{array}{llll}\text { Politics } & \text { (JGP), } & 1(2 & \text { SE-Articles). https://e- }\end{array}$ journal.iyb.ac.id/index.php/jgp/article/view/204

Arwin, Agustang, A., Ihsan, A., \& Suhaeb, F. (2015). POVERTY AND 
MODERNIZATION IN BAJO FISHING COMMUNITY. International Journal of Academic Research, 7(Vol. 7. No. 3. May, 2015).

Asri, A., Kasnawi, T., \& Agustang, A. (2019). Actors' Social Tensions on Traditional Birth Attendants and Midwife Partnerships in Childbirth Assistance (Sociology of Health Study in Bulukumba Regency). IOSR Journal Of Humanities And Social Science (IOSR-JHSS), 24(Issue 1, Ser. 10), 20-27.

Aswan, A., \& Agustang, A. (2017). PERILAKU ANOMI (STUDI PADA SISWA DI SMP NEGERI 21 MAKASSAR). JURNAL SOSIALISASI, 62-66.

Azis, F., Idris, R., \& Agustang, A. (2017). Involution Fisheries: Post-Study Model of National Program in Integrated Movement at Community Fishermen's Village Development Arungkeke, Jeneponto. Mediterranean Journal of Social Sciences, $\quad 8(1 \quad$ SE-Articles $), \quad 441$. https://www.richtmann.org/journal/index.php/mjss/article/view/9713

Badwi, A., Agustang, A., \& Adam, A. (2018). Individual Cognitive Dissonance in Society on Condom (A Sociology of Health Study in Makassar City). IOSR Journal Of Humanities And Social Science (IOSR-JHSS), 23(Issue 8, Ver. 7), 14-19.

Badwi, A., Agustang, A., \& Adam, A. (2020). Individual Cognitive Dissonance in Society on Condom (A Sociology of Health Study in Makassar City).

Bastiana, B., Jumadi, J., Herman, H., \& Agustang, A. D. M. P. (2019). Pelatihan penulisan Penelitian Tindakan Kelas bagi guru SMP Negeri 1 Duampanua Kabupaten Pinrang. Seminar Nasional Pengabdian Kepada Masyarakat, 2019(2).

Bebang, M., \& Agustang, A. (2021). THE SOCIAL ACTION OF THE TEACHERS IN HANDLING INDISIPLINARY STUDENTS AT SMP NEGERI 36 MAKASSAR, SOUTH SULAWESI, INDONESIA. 20(5), 5792-5796. https://doi.org/10.17051/ilkonline.2021.05.652

Bebang, M., Agustang, A., \& Samad, S. (2021). THE SOCIAL ACTION OF THE TEACHERS IN HANDLING INDISIPLINARY STUDENTS AT SMP NEGERI 36 MAKASSAR, SOUTH SULAWESI, INDONESIA. Elementary Education Online, 20(5), 5792-5796.

Bintaha, M., Salman, D., Agustang, A., \& Suhaeb, F. W. (2014). THE ROLE OF SOCIAL CAPITAL TOWARD SOME OTHER CAPITALS FOR RURAL ADVANCEMENT. International Journal of Academic Research, 6(5).

Burchanuddin, A., Agustang, A., Adam, A., \& Alim, A. (2021). Cultural Reproduction in the Socio-political Context of Bone District, South Sulawesi, Indonesia.

Daming, M., Agustang, A., Idkhan, A. M., \& Rifdan, R. (2021). IMPLEMENTASI KEBIJAKAN MAKASSAR RECOVER DALAM 
PENANGANAN COVID-19 DI KOTA MAKASSAR. JISIP (Jurnal Ilmu Sosial Dan Pendidikan), 5(4).

Dirawan, G. D. (2015). FOSTERING COLLABORATION STREET CHILDREN IN MAKASSAR. Man In India, 95(3), 569-576.

Djalante, A., Agustang, A., Tahmir, S., \& Sahabuddin, J. (2018). A Disadvantaged Tribe in Bajoe Village. Bone Regency: A Phenomenological Research on Bajo Tribe's Social Life in Bone Regency, South Sulawesi.

Djamaluddin, M., Agustang, A., Idkhan, A. M., \& Rifdan. (2021). Pengaruh Implementasi Corporate Social Responsibility PT. Vale Terhadap Kesejahteraan Hidup Masyarakat. Journal Governance and Politics $(J G P)$, $1(2$

SE-Articles). https://jurnal.iyb.ac.id/index.php/jgp/article/view/200

Edyanto, E., Agustang, A., Idkhan, A. M., \& Rifdan, R. (2021). Implementasi Kebijakan Otonomi Khusus (Otsus) Papua. JISIP (Jurnal Ilmu Sosial Dan Pendidikan), 5(4).

Erni, E., \& Agustang, A. (2021). PENGARUH TEMAN SEBAYA TERHADAP PERILAKU BOLOS DI KALANGAN PESERTA DIDIK SMK HANDAYANI MAKASSAR. Pinisi Journal of Sociology Education Review, 1(1), 97-102.

Firdaus, F. (2017). Permandian Wae Pellae (Konstruksi Fisik Spasial dan Perubahan Masyarakat Sinjai). Equilibrium: Jurnal Pendidikan, 5(1), 15-20.

Haerul, H., Agustang, A., Idhan, A. M., \& Rifdan, R. (2021). Online Learning Challenges in School. Jurnal Office, 7(2), 215-224.

Hairuddin, Agustang, A., Manda, D., \& Jumadi. (2018). Dynamics of Social Behavior of Using Condoms in Brothel at Jalan Nusantara, Makassar City (Sociology of Health and Illness Review). IOSR Journal Of Humanities And Social Science (IOSR-JHSS), 23(Issue 3, Ver. 11), 3339.

Haniah, S., Agustang, A., \& Samad, S. (2014). SOCIAL ACTION IN THE CLASSROOM: ANALYSIS OF EDUCATIONAL SOCIOLOGY ON INTERACTION BETWEEN TEACHER AND STUDENT IN SMP KARTIKA CHANDRA MAKASSAR. International Journal of Academic Research, 6(4).

har, M., Agustang, A., Adam, A., \& Upe, A. (2021). Online Learning and Distortion of Character Education in the Covid-19 Pandemic Era. Webology, 18(Special Issue 04), 566-580. https://doi.org/10.14704/web/v18si04/web18149

Hariani, H., Oruh, S., \& Mustari, N. (2021). GAMBARAN POLA ASUH ANAK PADA IBU YANG BEKERJA DI KELURAHAN KARANG ANYAR 
KOTA MAKASSAR. Media Keperawatan: Politeknik Kesehatan Makassar, 12(1), 1-6.

Harman, H., \& Agustang, A. (2020). PERUBAHAN SOSIAL MASYARAKAT PERMANDIAN WAE TUO DESA WAE TUO KECAMATAN KAJUARA KABUPATEN BONE. Jurnal Sosialisasi: Jurnal Hasil Pemikiran, Penelitian Dan Pengembangan Keilmuan Sosiologi Pendidikan, 2, 1-7.

Hermansya, H. (2014). Pengaruh kompetensi profesional guru sosiologi Terhadap Hasil Belajar Ssiswa di SMA Negeri 1 Soppeng Riaja Kabupaten Barru. Skripsi. Dibimbing oleh Prof. Dr. Andi Agustang, M. Si dan H. Dr Muhammad syukur, M, Si. Program Studi Pendidikan Sosiologi Fakulta. universitas negeri makassar.

Hikmah, N., \& Agustang, A. (2017). PERAN POST TEST TERHADAP MOTIVASI BELAJAR PADA MATA PELAJARAN SOSIOLOGI SISWA DI SMA NEGERI 11 MAKASSAR. JURNAL SOSIALISASI.

HIKMAH, N., \& AGUSTANG, A. (2016). PERAN POST TEST TERHADAP MOTIVASI BELAJAR SISWA PADA MATA PELAJARAN SOSIOLOGI DI SMA NEGERI 11 MAKASSAR. Universitas Negeri Makassar.

Idrus, I. I., Salman, D., \& Agustang, A. (2021). Commodification of Environmental Discourse in the Process of Producing Space in Bukit Baruga Housing, Makassar. IOP Conference Series: Materials Science and Engineering, 1125(1), 12087.

Irwan, A. A., Adam, A., \& Upe, A. (2021). Community Empowerment Strategy towards a Sustainable Rural Community-based Tourısm Village. Turkish Online Journal of Qualitative Inquiry (TOJQI), 12(5), 2065-2076.

Irwan, I., \& Agustang, A. (2021). Strategi Keberdayaan Masyarakat Menuju Desa Wisata Berbasis Masyarakat Yang Berkelanjutan. Seminar Nasional LP2M UNM.

Ismanto, Agustang, A., \& Idkhan, A. M. (2021). Pengaruh Kompensasi Finansial Terhadap Produktivitas Kerja Karyawan Pada PT PLN (PERSERO) Rayon Makassar Barat. Journal Governance and Politics (JGP), 1(2 SEArticles). https://e-journal.iyb.ac.id/index.php/jgp/article/view/202

Jumadi, Nurlela, Agustang, A., \& Darman. (2020). Social Actions of Galla Actors in the Kaemba Maros Traditional Village Community Sulawesi Selatan. 3rd International Conference on Social Sciences (ICSS 2020), 748-753.

Jumharyanti, J., \& Agustang, A. (2018). REMITANSI TENAGA KERJA INDONESIA PASCA KEPULANGAN DARI LUAR NEGERI (STUDI TKI DI DESA WORO KECAMATAN MADAPANGGA KABUPATEN BIMA NTB). Jurnal Sosialisasi: Jurnal Hasil Pemikiran, Penelitian Dan Pengembangan Keilmuan Sosiologi Pendidikan, 68-73.

Kasnawi, T., \& Agustang, A. (2014). TRADITIONAL ELITE ON MODERN 
POLITICS AT SOUTH SULAWESI. International Journal of Academic Research, 6(4).

Khaerun, K. (2014). Khaerun. Pengaruh kemampuan Manajerial Kepala Madrasah dan Kompetensi Pedagogik terhadap Kinerja Guru di Madrasah Tsanawiyah Kabupaten Gowa Provinsi Sulawesi Selatan.(Dibimbing oleh Andi Agustang dan Jumadi Tangko). universitas negeri makassar.

Kubangun, N., Agustang, A., \& Adam, A. (2020). Subaltern and Network Strategy Towards Fishermen Community in Aru Islands District. 3rd International Conference on Social Sciences (ICSS 2020), 585-588.

Kurniawan, A., \& Agustang, A. (2021). FAKTOR PENGHAMBAT TINGKAT KEDISIPLINAN SISWA DI SMAN 1 BANTAENG. Pinisi Journal of Sociology Education Review, 1(1), 120-126.

LEGIYO, L., Agustang, A., \& Hakim, M. (2018). Relasi Punggawa dan Sawi pada Bagan Perahu (Studi Kasus Nelayandi Pulau Balang Lompo Kabupaten Pangkep). UNIVERSITAS NEGERI MAKASSAR.

Leiwakabessya, J. E. M., Kasnawi, M. T., \& Agustang, A. (2021). The reality of the conflict of customary lands between the land of laha and the air force in ambon city (case study customary land in the land of laha). Turkish Online Journal of Qualitative Inquiry (TOJQI), 12(09), 4797-4804.

Lestari, S. A., \& Agustang, A. (2021). EFEKTIVITAS PEMBELAJARAN ONLINE PADA MATA PELAJARAN SOSIOLOGI DI SMA NEGERI 22 MAKASSAR. Pinisi Journal of Sociology Education Review, 1(2), $48-54$.

Mahendra, R., Agustang, A., Idkhan, A. M., \& Rifdan, R. (2021). Analisis Kinerja Aparatur Sipil Negara Dalam Pelayanan Publik. JISIP (Jurnal Ilmu Sosial Dan Pendidikan), 5(4).

Makmur, M. A., Agustang, A., \& Idkhan, A. M. (2021). Tingkat Kepuasan Masyarakat Terhadap Pelayanan Publik (Evaluasi Implementasi Program Beras Sejahtera Di Kota Palopo). Jurnal Sosio Sains, 7(2), 131-138.

Mallappiang, N., Agustang, A., \& Idkhan, A. M. (2021). Keberadaan Humas Dalam Menunjang Tridharma Perguruan Tinggi Universitas Indonesia Timur Makassar. Journal Governance and Politics (JGP), 1(2), 134-148.

Mario, M., Oruh, S., \& Agustang, A. (2021). Pola Relasi: Kontrak Radikalisme Terhadap Perempuan Milenial. Jurnal Sosialisasi: Jurnal Hasil Pemikiran, Penelitian Dan Pengembangan Keilmuan Sosiologi Pendidikan, 8, 72-86.

Masita, M., \& Agustang, A. (2020). Pergeseran Pemaknaan Perayaan Tradisi Saiyyang Pattu'duq di Tinambung Polewali Mandar. Phinisi Integration Review, 3(2), 173-178.

Masni, M., Oruh, S., \& Agustang, A. (2021). Tinjauan Sosiologis Penanganan 
Kasus Kekerasan Dalam Rumah Tangga Menurut UU PKDRT Oleh Pengadilan Negeri Pangkep. Jurnal Sosialisasi: Jurnal Hasil Pemikiran, Penelitian Dan Pengembangan Keilmuan Sosiologi Pendidikan, 8, 108117.

Mawarni, I. S., \& Agustang, A. (2021). KONSTRUKSI SOSIAL MASYARAKAT TERHADAP REALITAS SOSIAL TRADISI SI SEMBA'DI ERA GLOBALISASI (Studi penelitian di Daerah Kandeapi Tikala, Toraja Utara). Pinisi Journal of Sociology Education Review, 1(2), 1-10.

Mithhar, M., \& Agustang, A. (2021). Distorsi Pendidikan Karakter Siswa Dalam Pendidikan Jarak Jauh Pada Era Pandemi Covid-19 Di Kabupaten Majene, Indonesia. Seminar Nasional LP2M UNM.

Mufidah, N. F., \& Agustang, A. (2020). STUDI SOSIOLOGI PERNIKAHAN MUBARAK DI PONDOK PESANTREN HIDAYATULLAH MAKASSAR. Jurnal Sosialisasi: Jurnal Hasil Pemikiran, Penelitian Dan Pengembangan Keilmuan Sosiologi Pendidikan, 1, 1-8.

Muhammad, S., Agustang, A., \& Samad, S. (2015). SOCIAL MOVEMENT IN A MINING PROJECT: A STUDY OF SOROWAKOAN CONTENTIOUS POLITICS TOWARDS PT VALE INDONESIA, TBK. IN SOROWAKO, SOUTH SULAWESI. International Journal of Academic Research, 7(Issue ID: IJ15V7N3).

Muis, I., Agustang, A., \& Adam, A. (2020). Lansia Miskin: Demografi Sosial, Distribusi Pekerjaan, Masalah Kesehatan \& Perlindungan Sosial.

Mukti, I., Oruh, S., \& Agustang, A. (2021). Efek Pemberitaan Kekerasan Di Media Sosial Terhadap Citra Negatif Kota Makassar. JISIP (Jurnal Ilmu Sosial Dan Pendidikan), 5(4).

Muslimin, A., Idris, R., \& Agustang, A. (2015). CHILDREN AND SOCIAL ENVIRONMENT OF EDUCATION. International Journal of Academic Research, 7.

Mustadjar, M., \& Agustang, A. (2020). Pergeseran Pola Interaksi Sosial (Studi Pada Masyarakat Banggae Kabupaten Majene). Phinisi Integration Review, 3(2), 138-149.

Nasrullah, M., Agustang, A., \& Idhan, A. M. (2021). Utilization of Information Technology at the Mangarabombang District Office. Jurnal Ad'ministrare, 8(1), 339-346.

Nismawati, N., Oruh, S., \& Agustang, A. (2021). Eksistensi Tari Kabasaran Pada Masyarakat Minahasa. Jurnal Ilmiah Mandala Education, 7(4).

Nonci, N., Salman, D., \& Agustang, A. (2014). SILARIANG: STUDY OF THE SOCIAL CONSTRUCTION OF ETHNIC IN MAKASSAR IN GOWA DISTRICT. International Journal of Academic Research, 6(1).

Nur, S., Andi Agustang, \& Arlin Adam. (2020). Uninhabitable Home: Portraits of 
Poverty in Cities. Indonesian Journal of Social and Environmental Issues (IJSEI), 1(3 SE-), 234-238. https://doi.org/10.47540/ijsei.v1i3.81

Nurbaety, A., Torro, S., \& Agustang, A. (2015). REDUKSI PERAN GOLONGAN BANGSAWAN BUGIS DALAM KEHIDUPAN SOSIAL DI DESA SANREGO KECAMATAN KAHU. FIS.

Nurdin, N., Salman, D., Agustang, A., \& Malago, J. (2021). The Effect of Social Support and Gratitude on Resilient Persons with Disabilities in Makassar City. IOSR Journal of Humanities And Social Science (IOSR-JHSS), 12(5), 14-21.

Nursafitra, M., Agustang, A., Idkhan, A. M., \& Nurwiwiana. (2021). Pengaruh Disiplin Kerja dan Komitmen Organisasi Terhadap Kinerja Pegawai di Kantor Dinas Kependudukan dan Pencatatan Sipil Kabupaten Enrekang. Journal Governance and Politics (JGP), $1(2$ SE-Articles). https://jurnal.iyb.ac.id/index.php/jgp/article/view/203

Nursinah, Agustang, A., Adam, A., \& Bastiana. (2021). RELAPSE BEHAVIOR OF NAPZA ABUSE AFTER REHABILITATION IN MAKASSAR CITY. PalArch's Journal of Archaeology of Egypt/Egyptology, 18(08), 1845-1854.

Oruh, S. (2021). Analisis faktor Keaktifan Kader dalam Kegiatan Posyandu. Jurnal Ilmiah Kesehatan Sandi Husada, 10(1), 319-325.

Oruh, S., \& Agustang, A. (2019). Pengaruh Pengetahuan Keluarga, Stigma Masyarakat dan Kepatuhan Minum Obat Terhadap Kekambuhan Penyakit Gangguan Jiwa di Kota Makassar. 53(9). https://doi.org/10.1017/CBO9781107415324.004

Oruh, S., \& AGUSTANG, A. (2019). PENGARUH PENGETAHUAN KELUARGA, STIGMA MASYARAKAT DAN KEPATUHAN MINUM OBAT TERHADAP KEKAMBUHAN PENYAKIT GANGGUAN JIWA DI KOTA MAKASSAR.

Oruh, S., Agustang, A., \& Bagu, A. A. (2017). KEJADIAN HEROPNAM GANGGUAN JIWA DAN FAKTOR YANG MEMPENGARUHI PADA RUMAH SAKIT KHUSUS DAERAH DADI PROVINSI SULAWESI SELATAN.

Oruh, S., Agustang, A., \& Bagu, A. A. (2020). KEJADIAN HEROPNAM GANGGUAN JIWA DAN FAKTOR YANG MEMPENGARUHI PADA RUMAH SAKIT KHUSUS DAERAH DADI PROVINSI SULAWESI SELATAN.

Oruh, S., \& Nur, H. (2021). Perilaku Masyarakat Pesisir di Hutan Mangrove Desa Balangdatu Kabupaten Takalar. Phinisi Integration Review, 4(2), 292300.

Oruh, S., Theresia, M., \& Agustang, A. (2019). KESEJAHTERAAN PSIKOLOGIS. Researchgate.Net. 
Pettalongi, A., Idris, R., Kasnawi, T., \& Agustang, A. (2015). PROMOTING SOCIAL VALUES IN BUILDING SOCIAL INTERACTION AMONG INTER-ETHNICAL STUDENTS IN SMA KARUNA DIPA, PALU. International Journal of Academic Research, 7.

Rachim, A., Lolo, T. R. A., \& Agustang, A. (2017). RELATIONS AUTHORITY.

Rahman, B., Agustang, A., \& Samad, S. (2015). HEGEMONIC SOCIAL RELATION, A STUDY OF SOCIOLOGY ON OUTSOURCING PRACTICE. International Journal of Academic Research, 7.

Rahman, N., Agustang, A., Akib, H., \& Tahmir, S. (2015). ANALYSIS OF THE DETERMINANT FACTORS OF IN THE LEGISLATIVE PROCESS OF REGIONAL HOUSE OF PEOPLES'REPRESENTATIVES IN TAKALAR REGENCY. International Journal of Academic Research, 7.

RAHMAN, S. (2014). Industri Pabrik dan Masyarakat Lokal di Pinggiran Kota Makassar: Kasus Dua Komunitas Desa Sekitar PT. Kawasan Industri Makassar,(dibimbing oleh HM Idrus Abustam, Andi Agustang dan H. Heri Tahir). universitas negeri makassar.

Rajab, M. A., Oruh, S., \& Agustang, A. (2021). Persepsi Masyarakat Lokal terhadap Ekowisata Mangrove Kuri Caddi Desa Nisombalia Kabupaten Maros. Pepatudzu: Media Pendidikan Dan Sosial Kemasyarakatan, 17(2), 166-172.

Ramlafatma, R., Oruh, S., \& Agustang, A. (2021). Efektivitas Pendidikan Moral Dalam Pembentukan Karakter Siswa Di TK Islam Terpadu Asa Sumbawa. Jurnal Ilmiah Mandala Education, 7(4).

Rasyid, D., Agustang, A., Syukur, M., Usman, S., \& Marzuki, M. (2021). Social Transformation of Indonesian Older Adults in Suburbs: An Exploratorydescriptive Qualitative Study. Ethno Med, 15((1-2)), 44-52.

Rasyid, R., Agustang, A., Agustang, A. T. P., Bastiana, B., \& Najamuddin, N. (2020). Analisis Faktor Yang Mempengaruhi Status Kemiskinan Rumah Tangga Pada Wilayah Central Bussiness District (CBD) di Kota Makassar. Majalah Geografi Indonesia, 34(1), 43-52.

Reskiawan, M. M. N., \& Agustang, A. (2021). SISTEM SEKOLAH BERASRAMA (BOARDING SCHOOL) DALAM MEMBENTUK KARAKTER DISIPLIN DI MAN 1 KOLAKA. Pinisi Journal of Sociology Education Review, 1(2), 125-133.

Rieuwpassa, S., Agustang, A., \& Adam, A. (2020). Sustainable Peace Development In Ambon (An Analysis Study In Negeri Hila And Dusun Hila Tanah Putih). INTERNATIONAL JOURNAL OF SCIENTIFIC \& TECHNOLOGY RESEARCH, 9(2), 477-480.

Risal, R., Agustang, A., \& Syukur, M. (2021). Peranan Perempuan Tani dalam Meningkatkan Ekonomi Keluarga di Kelurahan Bonto Langkasa Kecamatan Bissappu Kabupaten Bantaeng. Phinisi Integration Review, 
4(2), 282-291.

Rongrean, B., Abustan, I., \& Agustang, A. (2015). THE SOCIAL DYNAMICS OF PEDICAB DRIVER TOWARD CLIMATE CHANGES IN MAKASSAR. International Journal of Academic Research, 7.

Rusli, M., Bulkis, S., \& Agustang, A. (2018a). MAKNA PERAN DAN MODAL SOSIAL PEREMPUAN NELAYAN BAJO (Studi Fenomenologi di Pesisir Pantai Soropia Kabupaten Konawe). UNIVERSITAS NEGERI MAKASSAR.

Rusli, M., Bulkis, S., \& Agustang, A. (2018b). Usage of Social Capital in Supporting the Welfare of the Coastal Community. IOSR Journal Of Humanities And Social Science (IOSR-JHSS), 23(Issue 8, Ver. 2), 26-32.

Saeni, R., \& Agustang, A. (2014). INDUSTRIAL FACTORY AND LOCAL COMMUNITIES ON THE MARGINAL CITY OF MAKASSAR. International Journal of Academic Research, 6(4).

Safar, M., Agustang, A., \& Adam, A. (2017). PSEUDO AKTOR POLITIK (Studi Genealogi Kekuasaan di Sulawesi Tenggara Indonesia). Pascasarjana.

Sahabuddin, A., Agustang, A., \& Idkhan, A. M. (2021). Fungsi Leadership dalam Peningkatan Pelayanan Publik di Kantor Kecamatan Makassar. Journal Governance and Politics (JGP), $1(2 \quad$ SE-Articles). https://jurnal.iyb.ac.id/index.php/jgp/article/view/207

Sahabuddin, E., Agustang, A., Manda, D., \& Oruh, S. (2020). Partisipasi Sosial Dalam Pemenuhan Activity Daily Living (Adl) Orang Dengan Gangguan Jiwa Di Kota Makassar. Phinisi Integration Review, 3(2).

Salmah, A. U., Idris, R., Agustang, A., \& Maidin, A. (2013). Socio-Cultural Transformation of Early Detection on Breast Cancer Suspect in Wahidin iSudirohusodo Hospital, Makassar Indonesia.

Samanlangi, A. I., Agustang, A., Adam, A., \& Alim, A. (2021). Disconnectivity Social of Conflict in the Circle of Iron Ore Mine in Bone Regency, South Sulawesi, Indonesia. International Journal of Criminology and Sociology, 10, 963-973.

Sanusi, D., Agustang, A., \& Idkhan, A. M. (2021). Pengembangan Sumber Daya Manusia Dalam Meningkatkan Pelayanan Akademik Di Universitas Puangrimaggalatung Sengkang . Journal Governance and $\begin{array}{llll}\text { Politics } & \text { (JGP), } & \text { SE-Articles). }\end{array}$ https://jurnal.iyb.ac.id/index.php/jgp/article/view/205

Sapulette, A. A., Agustang, A., \& Syukur, M. (2018). Actor Construction in the Frame of Diversity to Achieve Social Harmony in the Life of Tamilouw Village Society Seram Island-Maluku. IOSR Journal Of Humanities And Social Science (IOSR-JHSS), 23(Issue 2, Ver. 4), 54-60.

Sari, R. P., \& Agustang, A. (2021). PERAN GANDA IBU RUMAH TANGGA (STUDI KASUS PADA TUKANG CUCI MOBIL/MOTOR). Pinisi 
Journal of Sociology Education Review, 1(2), 106-113.

Suardi, Agustang, A., \& Jumadi. (2020). A., \& Jumadi.(2020b). The Symbolic Violence Towards Private School Students Through The Frame Stereotype In Bantaeng District Of Indonesia. The International Conference on Innovations in Social Sciences and Education, 578-588.

Suardi, Agustang, A., \& Jumadi. (2021a). DOMINATION OF THE POWER OF QUALITY AND QUANTITY OF STATE SCHOOL EDUCATION AGAINST PRIVATE SCHOOLS AS FACTORS CAUSING SYMBOLIC VIOLENCE OF STUDENTS IN BANTAENG DISTRICT. PROCEEDING 1st INTERNATIONAL CONFERENCE (On Health, Education, and Computer Science Technology), 1(pertama), 246-259.

Suardi, S., Agustang, A., \& Jumadi, J. (2021b). Dominasi Sekolah Negeri Terhadap Sekolah Swasta Sebagai Penyebab Kekerasan Simbolik Terhadap Siswa Sekolah Swasta. Jurnal Ilmiah Muqoddimah: Jurnal Ilmu Sosial, Politik Dan Hummanioramaniora, 5(2).

Sulaiman, U., Idris, R., Ardi, M., \& Agustang, A. (2014). The Pattern of Cooperation and Poorness: A Seaweed Farming Community in Indonesia. International Journal of Academic Research, 6(5), 239-242.

Sumai ${ }^{1}$, S., Agustang, A., Adam, A., \& Obie, M. (2020). Resilience in Children of Drug Abuse Families: A Case in Pattingalloang, Makassar City, Indonesia.

Sumitro, S., Oruh, S., \& Agustang, A. (2021). Eksistensi Nilai Sosial Budaya Ndeu Paki Oi Mbaru Pada Masyarakat Donggo Kabupaten Bima. Jurnal Ilmiah Mandala Education, 7(4).

Suparman, Oruh, S., \& Agustang, A. (2021). Dinamika Sosial Kelompok Tani (Studi Kasus Petani Bawang Merah Desa perangian Kecamatan Baraka Kabupaten Enrekang). JIIP-Jurnal Ilmiah Ilmu Pendidikan, 4(6), 406414.

Sutrisno, S., \& Agustang, A. (2018). Peranan Pengawas Sekolah Terhadap Pelaksanaan Kurikulum 2013 Di SMA Negeri 17 Makassar. Jurnal Sosialisasi: Jurnal Hasil Pemikiran, Penelitian Dan Pengembangan Keilmuan Sosiologi Pendidikan, 100-105.

Syaharuddin, S., Agustang, A., Idkhan, A. M., \& Rifdan, R. (2021). STRATEGI DINAS SOSIAL DALAM PENANGANAN ANAK JALANAN DI KOTA MAKASSAR. JISIP (Jurnal Ilmu Sosial Dan Pendidikan), 5(4).

Syamsul, A. (2014). Remaja penjajah seks komersial kota Makassar. Skripsi Sosiologi, Fakultas Ilmu Sosial, Universitas Negeri Makassar, yang di bimbing oleh. Firdaus W. Suhaeb sebagai pembimbing satu dan Andi Agustang sebagai pembimbing dua. universitas negeri makassar.

Syamsul, B., Idrus, A., Jumadi, S., \& Edwar, P. (2014). “A'PA ALLIRI”: THE SOCIAL FUNCTION OF LOCAL INSTITUTION AT MATAJANG 
SOCIETY. INTERNATIONAL JOURNAL of ACADEMIC RESEARCH, 6(6), 121-125.

Syukurman, S., Agustang, A., \& Adam, A. (2020). Peluang dan Tantangan Lembaga Pendidikan Islam (Ditinjau dari Sosiologi Agama di Desa Doridungga). EDU SOCIATA (Jurnal Pendidikan Sosiologi), 3(2), 7187.

Thamrin, H., Agustang, A., Adam, A., \& Alim, A. (2021). Disrupsi Modal Sosial Stunting di Sulawesi Selatan, Indonesia (Studi Kasus Pada Keluarga 1000 HPK di Kabupaten Bone dan Enrekang). Seminar Nasional LP2M UNM.

Thamrin, M., Agustang, A., Adam, A., \& Alim, A. (2021). Disruption of Stunting Social Capital in South Sulawesi, Indonesia (Case Study on 1000FDL Families in Bone and Enrekang Districts). Indian Journal of Public Health Research \& Development, 12(2).

Tinri, M. D. N. (2018). Hotels and Restaurant Tax Revenues Management.

Triono, T., Agustang, A., Idkhan, A. M., \& Rifdan, R. (2021). Motivasi Kerja Pegawai Dalam Pelayanan Publik. JISIP (Jurnal Ilmu Sosial Dan Pendidikan), 5(4).

Ufie, A., Oruh, S., \& Agustang, A. (2021). Maintaining Social Harmony Through Historical Learning Based on Local Wisdom of Indigenous Peoples in Maluku. Historia: Jurnal Pendidik Dan Peneliti Sejarah, 5(1), 31-40.

UMAR, S. (2014). Pola Kerjasama dan Ketidaksejahteraan Komunitas Petani Rumput Laut di Kecamatan Ujung Loe Kabupaten Bulukumba (Dibimbing oleh Promotor Rabihatun Idris serta Kopromotor Muhammad Ardi dan Andi Agustang). universitas negeri makassar.

Umasangaji, N. K., Agustang, A., Adam, A., \& Alim, A. (2021). Dampak Pandemi Covid-19 dan Pembelajaran Daring di Kampung Atas Air Balikpapan. Seminar Nasional LP2M UNM.

Urbach, N., \& Agustang, A. (2019). PREFERENSI ORANG TUA DALAM MENYEKOLAHKAN ANAKNYA DI DESA AMOLA KECAMATAN BINUANG KABUPATEN POLEWALI. JURNAL SOSIALISASI, 89-94.

Usman, A., Agustang, A., \& Idkhan, A. M. (2021). Penerapan Pelayanan Prima di Rumah Sakit Paru BBPM Makassar. Journal Governance and Politics (JGP), $\quad l(2 \quad$ SE-Articles). https://jurnal.iyb.ac.id/index.php/jgp/article/view/206

Wardah, S., Salman, D., Agustang, A., \& Fahmid, I. M. (2017). The Contestation of Organic and Non-Organic Agricultural Knowledge in Sustainable Agriculture. Mediterranean Journal of Social Sciences, 8(2 SE-Articles), 245.

https://www.richtmann.org/journal/index.php/mjss/article/view/9883

Wardiani, I., \& Agustang, A. (2018). Dampak Pekerjaan Orang Tua Pengrajin 
Emas Terhadap Pendidikan Anak di Kelurahan Borong Kecamatan Manggala Kota Makassar. UNIVERSITAS NEGERI MAKASSAR.

Wihdania, W., \& Agustang, A. (2020). Pernikahan Tolotang Di Kelurahan Amparita Kecamatan Tellu Limpoe Kabupaten Sidenreng Rappang. Phinisi Integration Review, 3(2), 165-172.

WULAN, S. (2014). Peranan Media Pembelajaran Dalam Meningkatkan Motivasi Belajar Sosiologi Pada Siswa SMA PGRI Galesong. Skripsi. Dibimbing oleh Andi Agustang dan Hj. Musdaliah Mustadjar Program Studi Pendidikan Sosiologi. Fakultas Ilmu Sosial, Universitas Negeri Makassar. universitas negeri makassar.

Yakobus, I. K., Kasnawi, T., Agustang, A., \& Gani, H. A. (2019). Hybridization of the Poso Conflict Resolution Discourse.

Yudhar, A. N., Agustang, A., \& Sahabuddin, J. (2021). Habituation of character values in junior high school students. Cypriot Journal of Educational Sciences, 16(2), 659-668.

Yunita, I., \& Agustang, A. (2021). Ketidakmerataan Bantuan Langsung Tunai Dimasa Pandemi Covid-19 Pada Masyarakat Kurang Mampu di Desa Carawali Kabupaten Sidrap. Pinisi Journal of Sociology Education Review, 1(2), 181-191.

Yusmuliadi, Y., \& Agustang, A. (2021). PERANAN OSIS DALAM MEMBENTUK KARAKTER PEDULI SOSIAL SISWA DI SMA NEGERI 3 BARRU. Pinisi Journal of Sociology Education Review, 1(1), 44-53.

Yusuf, M., Agustang, A., Idkhan, A. M., \& Rifdan, R. (2021). Transformasi Lembaga Koperasi Di Era Industri 4.0. JISIP (Jurnal Ilmu Sosial Dan Pendidikan), 5(4). 